\title{
The Role of Self-Supporting Extension Agent in Institutional Development of Farmers in Sijunjung Regency and West Pasaman Regency
}

\author{
Hery Bachrizal Tanjung ${ }^{1}$, Zulvera ${ }^{1}$, Rafnel Azhari ${ }^{1}$, Lucy Natami Figna ${ }^{1}$ \\ ${ }^{1}$ Faculty of Agriculture, Agricultural Faculty, Andalas University, Padang, Indonesia
}

Article Info

Received:

10 November 2019

Accepted:

05 February 2020

Published:

29 February 2020

Competing Interest:

The authors have declared that no competing interest exists.

\section{Corresponding Author:}

Hery Bachrizal Tanjung, Faculty of

Agriculture, Agricultural Faculty,

Andalas University, Padang,

Indonesia

Email: bbtanjung25@yahoo.com

(C) 2020 The Authors. This is an open access article under the CC BY license.

\begin{abstract}
The advancement of the agriculture sector in one region cannot be separated from the role of agricultural extension in the region. To cover the dearth of agricultural extension agents, self-supporting extension agents are recruited from farmers or private parties. This study aims to analyze the role of selfsupporting instructors in improving farmer institutions and analyze factors related to the role of self-supporting extension agents in improving farmer institutions. This research was a qualitative descriptive study, and it was conducted in West Pasaman and Sijunjung Regency with a sample of 38 people that are agricultural extension agents from Sijunjung Regency and Pasaman Regency. The results showed that self-supporting instructors play a significant role in improving farmer institutions; this is seen from $78 \%$ of self-supporting extension agents have a role in increasing farmer institutions. Factors related to the role of self-supporting extension agents in improving farmer institutions are (1) the age of agents, (2) the number of partners from farmer groups, and (3) the frequency of training attended by self-supporting extension agents. To increase the role of self-extension extension agents in the institutional development of farmers, it is recommended that institutions who manage the agricultural extension recruit self-supporting extension agents from the millennial generation and facilitate self-supporting extension agents to be able to participate in training related to farming in the agent's area of work.
\end{abstract}

Keywords: farmers, institutional development, role, self-supporting extension agents 


\section{Introduction}

The advancement of the agriculture sector in one region cannot be separate from the role of Agricultural Extension in the region. The Ministry of Agriculture has launched a program called "one extension agent for one village," but the number of extension agents has not met these needs which supposedly 74,957 extension agents (one extension agent for one village), and only about 72,056 extension agents were met (Ministry of Agriculture, 2019). The extension agents consisted of $37 \%$ civil servants, 23\% Civil Eextensions Agent 36\% selfsupporting and private extension agents, and Civil Servant Extension (CSE) Agents and study assignments $3 \%$ and $1 \%$ respectively (data processed from SIMLUHTAN, Ministry of Agriculture, 2019). The Ministry of Agriculture issued regulations regarding guidance for the training of self-supporting and private agricultural extension agents. This regulation was made to improve the performance of self-supporting and private agricultural extension agents through a revitalization of agricultural extension, and to achieve successful agricultural development. Self-supporting Agricultural Extension Agent (furthermore will be abbreviated into SAEA) is suitable with constitution Number 16 of 2006 to meet all the shortcomings of existing agents as a companion for civil servants.

To cover the shortage of agricultural extension agents, self-supporting extension agents are recruited from farmers or private parties. The position of selfsupporting agriculture instructors in Minister of Agriculture Regulation number 61 of 2008 is as the partner of CSE agricultural extension agents in conducting agricultural extension activities, both individually and integrated cooperation in agricultural extension programs, constitution level of government administration where extension activities are held. The existence of SAEA is independent to meet the needs of the main actors and agricultural business actors with the main task is to carry out agricultural extension activities to the main actors and business actors following the agricultural extension work plan which compiled based on the agricultural extension program in the working area. The number of agricultural development programs in districts and villages to encourage the agricultural sector makes self-supporting extension an important alternative in extension activities. This study wants to see and analyze the role of SAEA in improving farmer institutions.

\section{The Concept of Extension}

Extension in the general sense is a social science that studies the systems and processes of change in individuals and society so that changes can be achieved better than expected. According to Van den Ban and Hawkins (1999), counseling is an activity that involves people consciously communicating information to help others give their opinions so that they can make the right decision. According to Law (UU) Number 16 of 2006 concerning Agricultural, Fisheries and Forestry Extension Systems, what is called extension is a learning process for the main actors and business actors so that they are willing and able to help and organize themselves in accessing market information, technology, capital, and other resources, as an effort to increase productivity, business efficiency, income, and welfare, and increase awareness in the preservation of environmental functions.

\section{Self-supporting Agricultural Extension Agent (SAEA)}

The existence of SAEA has been explained in Law Number 16 and supported by Minister of Agriculture / Ministry of Agriculture Regulation No. 61 of 2010 concerning Guidelines for Developing Self-supporting and Private Extension Agents. SAEA is the main actor who succeeded in his efforts, and other members of the community who, with their awareness, were willing and able to become extension agents. That is, SAEA is someone who can develop himself as the main actor as well as a business actor who has succeeded in improving his standard of living, and then has the desire to share knowledge and skills with others. The main actors for agricultural activities are food crop farmers, horticultural farmers, planters and breeders, and their families.

\section{Materials and Methods}

This qualitative descriptive study was intended to explain and describe the observed variables. The research was conduct on March-October 2019. The location of the research was Sijunjung Regency and West Pasaman Regency. The study population was SAEA in Sijunjung Regency and West Pasaman Regency (there were 71 SAEA in Sijunjung and 80 in West Pasaman), who worked under the local Agricultural Extension Center (BPP). Sampling was focus on two BPPs from each regency, with a total sample of 38 people (19 from Sijunjung Regency and 19 from West Pasaman Regency), who have been select based on recommendations from the BPP and discussion with the research team. In addition to the sample, key informants in this study were the officer of the regency, district, and local village headman.

The instrument in this study was a questionnaire related to the research variables. Data collection was carrying out using methods: interviews, observation, documentation, and focused group discussions (FGD). Primary data were collect through direct interviews with respondents, both guided by questionnaires and in-depth with selected respondents, to explore the meaning of quantitative data. Secondary data were obtained from supplementary documents issued by the Department of Agriculture of Sijunjung Regency and West Pasaman Regency. To analyze the factors related to the role of the SAEA, a Spearman rank correlation analysis was performing with the help of the SPSS program. Then, to give deeper meaning, a descriptive qualitative analysis of the strengthening process of farmer institutions was also conduct. 


\section{Results and Discussion}

The study was conduct in Sijunjung Regency and West Pasaman Regency. Sijunjung Regency has an area of $2,745.73 \mathrm{~km}^{2}$ with a total population of 201,627 people. Sijunjung Regency consists of 8 districts, namely: Kamang Baru District, Tanjung Gadang, Sijunjung, Lubuk Tarok, IV Nagari, Kupitan, Koto VII and Sumpur Kudus. Each district has its own BPP. The second location in West Pasaman Regency in West Pasaman Regency is located between $00^{\circ} 33^{\prime}$ North Latitude to $00^{\circ} 11^{\prime}$ South Latitude and $99^{\circ} 10^{\prime}$ to $100^{\circ} 04^{\prime}$ East Longitude with an area of $3,864.02$ $\mathrm{km}^{2}$. There are 11 districts in West Pasaman Regency: Pasaman District, Luhak Nan Duo, Sasak Ranah Pasisia, Kinali, Gunung Tuleh, Talamau, Sungai Aur, Melintang Valley, Koto Balingka, Batahan, and Sungai Beremas.

\section{A. Characteristics of Research Respondents}

Research respondents consisted of 38 people (19 from Sijunjung Regency and 19 from West Pasaman Regency), who have been select based on recommendations from the BPP and discussion with the research team. Respondent characteristics observed in this study consisted of age, gender, education, land area, and length of time being SAEA, as presented in Table 1.

Table 1 shows $63.16 \%$ of the SAEA categorized as old, which can be interpret that they are considering to have had a lot of experience in agriculture. What experiences will certainly cause his competence to be even better. Some research results also show that age affects the performance of extension agents. Leilani and Jahi (2006) and Sapar et al., (2011) found that one's age affects the level of one's performance. Referring to the age category created by the Central Statistics Agency (2009) the age of the respondent extension was classification as productive age because the average age of the respondents ranged from 30-61 years.

Most SAEA respondents were male ( $92.11 \%)$, only 3 people $(7.89 \%)$ SAEA were female. Women who become SAEA are mostly women who do farm and have started marketing or processing products. This is in line with the opinion of Ban and Hawkins (1999) which stated that women have an important role in extension, which is in their communication and approach skills to other farmers. The existence of female extension agents is expected to bring closer the extension agents and the target community. The small number of women becoming SAEA at the study site occurred because of low interest, and areas of work that were difficult to reach.
The most SAEA education is the high school level $(55.26 \%)$, and 4 respondents $(10.53 \%)$ in the level of diploma and bachelor. According to Heliawaty (2009) the higher the formal education of farmers the more rational the mindset and reasoning they have, so that there will be more responses to innovations that being taught, this is in line because SAEA is also a farmer. Most SAEA (71\%) own land in the range of 0.25 ha 3.5 ha; which is mostly planted with rice, chili, corn, and parts of SAEA in West Pasaman planted oil palm, melons, and papaya. This farmer's land is an individual land in which the farm products are also individually sold.

Referring to Bandura (1997), a person's experience can be measure quantitatively based on the number of years a person works in the field that is undertaken. Most respondents have tenure as SAEA ranging from 1 - 4 years, only 2 agents who have tenure of more than 10 years; however, some agents have been long enough as SAEA but not included in the Decree (SK). Bryan and Glenn's research (2004) shows that work experience has a positive effect on new extension agents, while those who have worked longer will show the level of satisfaction from the client. The agent's work experience shows his skills in doing work, both in terms of technical and planning. Extension agents who have worked for a long time are certainly experienced in communicating and interacting with clients, so they can plan programs for farm development better. Thus, the work experience influences the performance of agricultural agents.

\section{B. The Role of SAEA in the Development of Farmer Institutions}

The role of SAEA in the development of farmer institutions is observed from the following components: (1) the activity of forming farmer groups, (2) the number of farmer groups built, (3) the frequency of visits to farmer groups, (4) activity on helping farmers in formulating group planning, (5) activity on helping farmers in analyzing farming, (6) Activity on motivating farmers to improve the class of farmer groups, (7) facilitating farmer groups in establishing business partnerships with related parties, (8) assisting farmers in marketing agricultural products. A description of the role of the SAEA in the development of farmer institutions is present in Table 2. 
Table 1. Respondents' Spread based on characteristics

\begin{tabular}{lllll}
\hline No. & Respondent Characteristics & Group & Amount & $\%$ \\
\hline 1 & Age & Young & 4 & 10,53 \\
& & Adult & 10 & 26,32 \\
& & Old & 24 & 63,16 \\
& \multirow{2}{*}{ Gender } & Male & 35 & 92,11 \\
& \multirow{2}{*}{ Education } & Female & Primary school & 7,89 \\
& & Junior High School & 1 & 2,63 \\
& & Senior High School & 6 & 15,79 \\
& & Diploma - Bachelor & 21 & 55,26 \\
4 & Land area & 0,25 ha $-3,5$ ha & 4 & 10,53 \\
& & 3,5 ha $-6,5$ ha & 27 & 71,05 \\
& & 6,5 ha $-9,5$ ha & 9 & 23,68 \\
5 & Time being SAEA & $1-4$ years & 2 & 5,26 \\
& & $5-9$ years & 30 & 78,95 \\
& & $10-14$ years & 6 & 15,79 \\
\end{tabular}

Tabel 2. The Role of SAEA in Farmer Institution Development

\begin{tabular}{|c|c|c|c|c|}
\hline No. & Role Aspects & Category & Amount & $\%$ \\
\hline \multirow[t]{2}{*}{1} & Forming farmer groups & Yes & 33 & 86,84 \\
\hline & & No & 5 & 13,16 \\
\hline \multirow[t]{3}{*}{2} & Number of partner farmer groups & $1-5$ groups & 25 & 65,79 \\
\hline & & $6-10$ groups & 11 & 28,95 \\
\hline & & $11-15$ groups & 2 & 5,26 \\
\hline \multirow[t]{2}{*}{3} & Visit partner farmer groups & Often & 22 & 57,89 \\
\hline & & Rarely & 16 & 42,11 \\
\hline \multirow[t]{4}{*}{4} & Assist farmers in formulating goals/farmer group planning & Yes & 34 & 89,47 \\
\hline & & No & 4 & 10,53 \\
\hline & Assist farmers in analyzing their farming & Yes & 30 & 78,95 \\
\hline & & No & 8 & 21,05 \\
\hline \multirow[t]{2}{*}{6} & Motivate farmers to improve the class of farmer groups & Yes & 36 & 94,74 \\
\hline & & No & 2 & 5,26 \\
\hline \multirow[t]{2}{*}{7} & $\begin{array}{l}\text { Facilitating farmer groups in establishing business partnerships with } \\
\text { related parties }\end{array}$ & Yes & 29 & 76,32 \\
\hline & & No & 9 & 23,68 \\
\hline \multirow[t]{2}{*}{8} & Assist farmers in marketing agricultural products & Yes & 25 & 65,79 \\
\hline & & No & 13 & 34,21 \\
\hline
\end{tabular}

From Table 2 it appears that most of the SAEA (who is also the Chair of the farmer group) became the pioneers of the creation of farmer groups. SAEA collects and holds consultations with farmers who are prospective group member, and prepares administrative requirements for group formation. The results of the meeting are then submitted to the local village government office to be made into a decree. The purpose of forming farmer groups was initially as a requirement for obtaining fertilizer and seed assistance from the government, but as the operations of farmer groups proceeding, farmer groups developed into learning spaces for member farmers. However, there are 13\% SAEA respondents who did not initiate the formation of farmer groups because initially, they were only members of farmer groups.

In addition to initiating the formation, SAEA also acts as a guide of the farmer's group. Twenty-two SAEA respondents conducted routine visits to farmer groups to discuss the sustainability of farmer group activities, such as making demonstration plots, 
Table 3. Respondents spread based on factors related to the role of the SAEA

\begin{tabular}{|c|c|c|c|c|}
\hline No. & Factors & Category & Amount & $\%$ \\
\hline \multirow[t]{3}{*}{1.} & \multirow[t]{3}{*}{ Honorarium during the extension activities } & Yes & 1 & 2,63 \\
\hline & & Always & 0 & 0,00 \\
\hline & & Never & 37 & 97,4 \\
\hline \multirow[t]{3}{*}{2.} & \multirow[t]{3}{*}{ Operational assistance to conduct extension activities } & Yes & 2 & 5,26 \\
\hline & & Always & 0 & 0,00 \\
\hline & & Never & 36 & 94,7 \\
\hline \multirow[t]{3}{*}{3.} & \multirow[t]{3}{*}{ Assistance with infrastructure during the extension activities } & Yes & 14 & 36,8 \\
\hline & & Always & 3 & 7,9 \\
\hline & & Never & 21 & 55,3 \\
\hline \multirow[t]{3}{*}{4.} & \multirow[t]{3}{*}{ Participate in training } & Often & 19 & 50,0 \\
\hline & & Rarely & 14 & 36,8 \\
\hline & & Never & 5 & 13,2 \\
\hline \multirow[t]{3}{*}{5.} & \multirow[t]{3}{*}{ Get an award / certificate } & Often & 4 & 10,5 \\
\hline & & Rarely & 8 & 21,1 \\
\hline & & Never & 26 & 68,4 \\
\hline \multirow[t]{2}{*}{6.} & \multirow[t]{2}{*}{ Has a special place to conduct meetings } & Yes & 21 & 55,3 \\
\hline & & No & 17 & 44,7 \\
\hline \multirow[t]{2}{*}{7.} & \multirow[t]{2}{*}{ Supporting institutions } & Available & 31 & 81,6 \\
\hline & & Not available & 7 & 18,4 \\
\hline \multirow[t]{3}{*}{8.} & \multirow[t]{3}{*}{$\begin{array}{l}\text { Coordination and consultation with civil servants extension } \\
\text { agents }\end{array}$} & Often & 32 & 84,2 \\
\hline & & Rarely & 4 & 10,5 \\
\hline & & Never & 2 & 5,3 \\
\hline \multirow[t]{3}{*}{9.} & \multirow[t]{3}{*}{ Make an activity report } & Often & 6 & 15,8 \\
\hline & & Rarely & 17 & 44,7 \\
\hline & & Never & 15 & 39,5 \\
\hline \multirow[t]{2}{*}{10.} & \multirow[t]{2}{*}{ Other positions in the community } & Yes & 32 & 84,2 \\
\hline & & No & 6 & 15,8 \\
\hline \multirow[t]{4}{*}{11.} & \multirow[t]{4}{*}{ Number of partner farmer groups } & 1 - 4 groups & 19 & 50,0 \\
\hline & & 5 - 9 groups & 17 & 44,7 \\
\hline & & 10 - 14 groups & 0 & 0,0 \\
\hline & & $>14$ groups & 2 & 5,3 \\
\hline
\end{tabular}

product marketing, and other businesses. Meetings are usually held once or twice a week, which takes place at the home of the head of the farmer group or the home of a member of the farmer group. This is in line with Syafriwan's (2013) research, in which extension agents play a role in providing guidance and helping farmer groups. Like what happens in the field when the agents do extension job, they use teaching aids as a tool to explain how the application is in the field, such as examples of the application of pesticides, good harvesting systems, and land clearing.

The number of partner farmer groups in each SAEA varies. It is required by the Regency Agriculture Office that each SAEA have at least 4 farmer groups under his guidance. However, some SAEA even guide farmer groups outside their working area, because there is some SAEA expertise that is not owned by farmers in other groups. Therefore, it is often the case that SAEA is routinely invited to conduct training, coaching, or field schools to other farmer groups outside its working area.

Darajat (2011) stated farmer groups are one of the efforts to empower farmers to increase productivity, income, and welfare of farmers. 34 SAEA respondents helped formulate group goals because most agents were group leaders who initiated the formation of groups. From the start, the group goals were formulated together with group members. In line with the Principal Tasks and Functions of the SAEA which has been regulated in the Regulation of the Minister of Agriculture Number: 61/Permentan/Ot.140/11/2008 concerning Guidelines for the Development of Self- 
Table 4. Correlation coefficients of factors related to the role of SAEA

\begin{tabular}{ll}
\hline Related factors & The role of the SAEA in the development of farmer institutions \\
\hline Age & $-0.372^{*}$ \\
Number of partner farmer groups & $0.326^{*}$ \\
Training Frequency & $0.331^{*}$ \\
\hline
\end{tabular}

Note: *significant at $\mathrm{p}<0.05$

supporting Agricultural Extension Agents and Private Agricultural Extension Agents which states that the Self-supporting or private extension agents play an active role in developing the institutions of the main actors and the Self-supporting or private extension agents compiles a plan for agricultural extension activities in coordination with local agricultural extension institutions.

The role of SAEA in assisting farmers to analyze their farming is good $(78.95 \%$ of extension agents assist farmers in conducting farm analysis). SAEA farmers have understood the analysis of cultivation and postharvest processing, often the SAEA provides farmers with input on how to fertilize, water, and even harvest techniques. Appreciation for farmers brought to the national event is the biggest motivation of SAEA in motivating the farmer group to move up their class. This is in line with the Principal Tasks and Functions of the SAEA which states that Self-supporting or private extension agents can play an active role in solving problems in developing businesses of agribusiness in their working areas. 29 people $(76.32 \%)$ SAEA respondents helped farmers in establishing partnerships with related parties, for example with the marketing agent of products. Even though farming products are still sold individually, SAEA can help farmers to market their products with a system of partner collaboration. For example, the results of chili farming can be marketed outside the regional market. This is also in line with one of the main tasks and functions of the SAEA that stated that SAEA has a role in developing cooperation and partnerships with related parties in the development of agribusiness businesses, the main actors, and business actors.

\section{Factors related to the Role of the SAEA in Farmer Institutional Development}

Table 3 shows $97 \%$ of SAEA claimed not receiving any honorariums in conducting extension activities; this is following the definition of SAEA, which is the main actor who succeeded in his business and other community members who, with their willingness and ability, become extension agents. In the Decree of the West PasamanRegency Agriculture Office, it was written that SAEA did not get a salary. The same for operational assistance, more than $90 \%$ of SAEA claimed not getting operational assistance. However, for the assistance of extension infrastructure, more than $50 \%$ of extension agents stated that they received assistance from the government, among others in the form of facilities for demonstration plots on farmland.
Training is one of the important activities that extension agencies should carry out to improve SAEA's ability to carry out its duties. However, the results of the study showed that $50 \%$ of SAEA claimed to frequently participate in training activities and $30 \%$ claimed to be rare. Information obtained in the field stated that the training was conducted by the District Agricultural Counseling Center and the Regency Agriculture Office.

Growing farmer groups is one of the extension activities in the context of developing farmer institutions. Table 3 shows that $94 \%$ of SAEA has 1 9 partner farmer groups. This amount is quite large when compared to local government requirements, that each SAEA has at least 4 farmer groups under his guidance.

From the quantitative analysis of the research data, the result shows that the factors related to the role of the SAEA in the development of farmer institutions were age, number of partner farmer groups, and the frequency of training undertaken. Correlation values of related factors are presented in Table 4.

The Spearman Rank correlation test results in Table 4 show, agent's age is related to its role in strengthening farmer institutions by -0.372 . There is a significantly negative relationship between age and the role of SAEA, so it can be stated that the younger the age of SAEA, the stronger its role in institutional development of farmers tends to be. The number of partner farmer groups is significantly positive with the role of the SAEA with a value of 0.326 ; which means that there is a tendency that the more farmer groups become agent's partners the stronger the role of SAEA in developing farmer institutions. The next factor was the frequency of training that SAEA participated in, which was significant-positively related to its role as a counselor with a coefficient value of 0.331; which means that there is a tendency that the higher the frequency of training that SAEA participated in relation to its role as an extension agent, the stronger the role of SAEA in developing farmer institutions.

\section{Conclusions}

The results showed that Agricultural Extension Agent (SAEA) had a role in improving farmer institutions, where the value was above $65 \%$ for all components of the role of extension agents in the farmer institutions' development. While the factors related to the role of the SAEA in improving farmer institutions are the age of extension agents, the number of partner farmer 
groups, and the frequency of training participated by Extension Agent.

From these conclusions, to enhance the role of the SAEA in developing farmer institutions, it is recommended that the Regency Agriculture Office, which is currently responsible for managing agricultural extension, be able to recruit advanced farmer youths as SAEA, and facilitate them to be able to participate in training related to his duty as Extension Agent.

\section{Acknowledgements}

Thank you to the Thank you to the primarily directed at the Faculty of Agriculture, University of Andalas as funders of research conducted by the author.

\section{References}

[1] Ministry of Agriculture. 2012. Technical Guidelines for Implementation of Self-Empowerment of Agricultural Extension Services Ministry of Agriculture. Jakarta (ID): Ministry of Agriculture

[2] Anantanyu S. 2009. Farmer Participation in Increasing Institutional Capacity of Farmer Groups (Case in Central Java Province). [Dissertation] Bogor. Bogor Agricultural Institute.

[3] Darajat, S. 2011. Farmers' Group, the Spearhead of the Future of Agriculture.

http:/ / www.pelita.or.id/baca.php?id=41182. Downloaded: 30 October 2019.

[4] Ministry of Agriculture. 2009. Guidelines for Implementing Guidelines for Empowerment of Non-Governmental Agricultural Extension Workers at the Ministry of Agriculture. Jakarta (ID): Ministry of Agriculture

[5] Iqbal, Muhammad. 2008. Constellation of Government Institutions and Non-Governmental Organizations in the PIDRA Program. Journal of Development Economics, FE UMS, Vol. 9, No.1, June. Pp.32-35. Surakarta: BPPE Faculty of Economics, Muhammadiyah University, Surakarta

[6] Leilani, Jahi. 2006 Performance of Agricultural Extension Workers in Several West Java Province Districts, Journal of Counseling, Bogor; IPB

[7] Mardikanto T. Agricultural Extension System. Surakarta (ID): UNS Press

[8] Soerjono Soekanto. Sociology an Introduction. Jakarta: Raja Grafindo Persada. 2002

[9] Sudarko. 2012.The Capability Level of Farmer Group Members in the Application of People's Coffee Farming Technology Innovation. JSEP. 6 (1): 1-11. Unej Press

[10] Sumardjo. 2012. Institutional and Competency of Extension Workers in Community Empowerment. Forum on Regional Development Institutions. April 21. Padang, West Sumatra

[11] Van den Ban AW. HS Hawkins. 1999. Agricultural Education. A.D. Herdiasti, translator. Yogyakarta: Canisius. Translation from: Agriculture Extension. 